\title{
Crop Yield and Nitrogen Bioavailability Mediated by Nitrogen Fertilization in Maize/Soybean Intercropping System with and without Rhizobium Inoculation
}

\author{
Nieven O. Fathi ${ }^{1}$
}

\begin{abstract}
Two plots experiments were conducted at the Soil Salinity and Alkalinity Laboratory at Alexandria, Egypt, to study the beneficial effects of nitrogen supply from soybean intercropped with maize on available nitrogen in soil, nitrogen uptake, and yield of maize. The results indicated that the highest grain yield of maize $\left(5581\right.$ kg.ha $\left.{ }^{-1}\right)$ was achieved in maize+soybean intercropping under the entired recommended rate (RR) of mineral nitrogen application (120 units of $\mathrm{N}$ as urea), and the lowest $\left(2280 \mathrm{~kg}^{\circ} \mathrm{ha}^{-1}\right)$ was achieved in maize+soybean intercropping in absence of mineral nitrogen application. Application of rhizobium to maize+soybean intercropping system significantly increased maize grain and above-ground biomass yields. On average of two years, maize grain of maize+soybean intercropping overyielded the sole maize by $58 \%$ (ranging from $0.9 \%$ to $99.96 \%$ ). Total land equivalent ratio (TLER), averaged over $\mathrm{N}$ levels, was 2.30 in maize+soybean, and 2.67 in soybean + maize intercropping with rhizobium over the 2 years of the study. The combination of mineral and rhizobium in maize+soybean intercropping system showed the highest values of $N$ concentrations in plant tissues compared with mineral or rhizobium plots individually. Also, there were significant positive relationships between $\mathbf{N}$ uptake and maize grain yield in the first season $[r=0.99,0.99,0.90,0.90$, and 0.86 for maize, soybean, maize + soybean intercropping, soybean + rhizobium, and maize + soybean + rhizobium, respectively]. Although, the intercropped maize and soybean plus rhizobium at $50 \%$ of $R R$ of $\mathrm{N}$ fertilizer was not yielded the highest corn grain, it is recommended that to be the best economic treatment.
\end{abstract}

Key Words: Intercropping System, Nitrogen Uptake, Nitrogen Availability, Maize/Soybean, Rhizobium

\section{INTRODUCTION}

The intercropping system is the combination between two or more crops in the same field and growing season. Intercropping, through more effective use of water, nutrients and solar energy, can significantly enhance crop productivity compare to sole crops (Francis 1989). The majority of intercropping systems may involve legume/cereal combinations (Ghosh 2004) due to its interspecific facilitation or complementarity (Loreau et al. 2001).However; cereal/cereal intercropping is popular and plays a role in intensive farming systems. Total grain yields have reached 10.0-13.3 $\mathrm{t} \mathrm{ha}^{-1}$ in wheat/maize systems ( $\mathrm{Li}$ et al. 2001) and $13.8 \mathrm{t} \mathrm{ha}^{-1}$ in barley/maize intercropping (Liu 2005) in which $\mathrm{N}$ application rates of up to 225$300 \mathrm{~kg} \mathrm{ha}^{-1}$ have been applied (Li et al.2001; Liu 2005).

Most studies on intercropping have focused on low input and low-output systems (Hauggaard-Nielsen and Jensen 2001) in order to develop organic farming systems. In contrast, intercropping in China has developed using intensive farming systems with high inputs and high outputs, typically cereal/cereal systems. However, cereal/cereal mixtures have not been extensively studied because they were expected to generate little added value to monocrops because of an anticipated prevalence of competitive rather than facilitative interactions. Sometimes intercrops are advantageous, not mainly through facilitation, but simply because of complementarity, e.g. in relay intercrops such as cotton/wheat intercrops in which the benefit is based mainly on a differentiation between component crops in the timing of interception of radiation (Zhang et al. 2007, Zhang et al. 2008). It has also been shown that interspecific interactions and soil nutrient levels affect agricultural ecosystem productivity (Cahill 2002). The effect of interspecific interactions on productivity varies with crop species combination (Sharaiha and Gliessman 1992).

There are two types of interspecific interactions, namely interspecific facilitation and competition (Vandermeer 1989). Interspecific facilitation occurs when one plant species enhances the growth of another plant species and has been observed mainly in legume/cereal systems such as soybean/corn and cowpea/corn (Allen and Obura1983), wheat/white lupine (Horst and Waschkies 1987), wheat/chickpea, faba bean/maize (Li et al.,2007), and peanut/maize (Zuo et al. 2000). The objectives of this study, therefore, were to evaluate the effects of maize/soybean intercropping in the presence and absence of rhizobium on available nitrogen in soil, nitrogen uptake, and yield of maize; and to evaluate its impact on mineral nitrogen fertilization rate, assuming the nitrogen supply from soybean.

\footnotetext{
${ }^{1}$ Salinity and Alkalinity Soils Research Laboratory, Agriculture Research Center, Alexandria, Ministry of Agriculture, (Egypt) Received May 12, 2014, Accepted June 22, 2014
} 


\section{Experimental Site}

The cemented plots experiments were conducted at the Soil Salinity and Alkalinity Laboratory at Alexandria, MALR, Egypt, This site lies between latitude $31^{0} 2^{\prime \prime} \mathrm{N}$, and longitude $29^{\circ} 6^{\prime \prime} \mathrm{E}$ with an elevation of about $-2.50 \mathrm{~m}$ below sea level. The average annual rainfall was $200 \mathrm{~mm}$ and the relative humidity during daytime was about $67.30 \%$ at the experimental site. The mean maximum temperature during August and September ranged between $30.9^{\circ} \mathrm{C}$ and $29.6{ }^{\circ} \mathrm{C}$. The soil of the experimental plots had a sandy clay loam texture with $341.20 \mathrm{gkg}^{-1}$ clay, $104.90 \mathrm{gkg}^{-1}$ silt and $553.90 \mathrm{gkg}^{-1}$ sand. The soil physical and chemical properties were determined as follows: $\mathrm{pH}$ and electrical conductivity in soil-paste extract (Richard, 1954); organic matter by dichromate oxidation method (Nelson and Sommers, 1982); cation exchange capacity (CEC) by IM NaOAC (Rhoades, 1982) and particle size distribution by the hydrometer method (Day, 1965). The calcium carbonate was measured by calcimeter method (Nelson, 1982); the amount of available P by $0.5 \mathrm{M}$ $\mathrm{NaHCO}_{3}$ method (Olsen and Sommers, 1982); available nitrogen by $2 \mathrm{M} \mathrm{KCl}$ method (Bremner and Mulvaney, 1982) and available potassium by $1 \mathrm{~N}$ ammonium acetate method (Knudsen and Peterson,1982). The soil physical and chemical properties of the soil are presented in Table (1).

\section{Experimental Set-up:}

Maize (Zea mays c.v. single hybride $30 \mathrm{~K} 8$, white pioneer) and/or soybean (Glycine max L.) were seeded in the cemented plots (dimension of $0.75 \mathrm{~m} \times 0.40 \mathrm{~m} \mathrm{x}$ $1.0 \mathrm{~m}$ ). Each plot was filled with a sandy clay loam soil. The treatments in both experiments consisted of the intercropping between soybean and maize (Fig.1) mediated by different rates of nitrogen fertilizer( $0,30,60$, and $120 \mathrm{~kg} \mathrm{~N})$ equivalent to $0,25 \%$, $50 \%$, and $100 \%$ of maize recommended requirements as recommended (120 kg of $\mathrm{N}$ as urea) by Ministry of Agriculture (MALR) in Egypt. The mineral nitrogen fertilizer was applied as urea in two equal doses: before sowing and 21 days after sowing of maize plants. The phosphorus fertilizer was applied at $30 \mathrm{~kg} \mathrm{P}_{2} \mathrm{O}_{5}$ as superphosphate $(15 \%)$ and potassium fertilizer was applied at $24 \mathrm{~kg} \mathrm{~K} \mathrm{~K}_{2} \mathrm{O}$ as potassium sulphate (48\%) before sowing. The experimental design was a split plot with four replicates of each treatment. Control treatment represented soil without any source of fertilizers.

Corn and/or soybean were inoculated with and without rhizobium sp. and sown in the plots during the growing season (May-September) in the two successive seasons, i.e., 2012 and 2013. The day length was about $14 \mathrm{hrs}$.and temperature range was $25-35{ }^{\circ} \mathrm{C}$. The seedlings were thinned to 6 plants per plot and were irrigated according to plant-water need. The plants were harvested (above ground shoot with ears) after 13 weeks from sowing.

The application of mineral nitrogen fertilizer to the soil cultivated with maize and/or soybean yielded a total of twelve treatments as follows:

$\mathrm{T} 1:$ maize $+0 \mathrm{~kg} \mathrm{~N}$ (control treatment)

T2: maize $+30 \mathrm{~kg} \mathrm{~N}$ (25\% of recommended rate,RR)

T3: maize $+60 \mathrm{~kg} \mathrm{~N}(50 \% \mathrm{RR})$

T4: maize $+120 \mathrm{~kg} \mathrm{~N}(100 \% \mathrm{RR})$

T5: maize + soybean $+0 \mathrm{~kg} \mathrm{~N}$

T6 : maize + soybean $+30 \mathrm{~kg} \mathrm{~N}$

T7: maize + soybean $+60 \mathrm{~kg} \mathrm{~N}$

T8: maize + soybean $+120 \mathrm{~kg} \mathrm{~N}$

T9: maize + soybean $+0 \mathrm{~kg} \mathrm{~N}+$ rhizobium

$\mathrm{T} 10:$ maize + soybean $+30 \mathrm{~kg} \mathrm{~N}+$ rhizobium

T11: maize + soybean $+60 \mathrm{~kg} \mathrm{~N}+$ rhizobium

T12 : maize + soybean $+120 \mathrm{~kg} \mathrm{~N}+$ rhizobium

\section{Soil Sampling and Analysis:}

Samples of soil were collected $(0-20 \mathrm{~cm})$ after fertilizers application before sowing and after harvesting of plants in the first and the second seasons. Each sample consisted of a mixture of three cores randomly collected from each plot, air-dried, ground, passed through a 2-mm sieve and analyzed for available-N (Bremner and Mulvaney, 1982).

\section{Plant Analysis:}

The plants of maize and soybean were harvested on September $15^{\text {th }}, 2010$ and 2011. The grains were separated from the rest of the plant. The plant samples were rinsed with tap water, and then rinsed with deionized water. The plant samples were then oven dried at $70{ }^{\circ} \mathrm{C}$ for $48 \mathrm{hrs}$ and weighed. The oven-dried plant tissues were ground using a stainless steel mill. Sub-samples of the dried ground materials were wetashed by sulfuric acid and hydrogen peroxide, diluted to a constant volume with distilled water and analyzed for total nitrogen (Jones, 2001).

The Dry matter production and grain yield are expressed on dry weight basis. The grain yield and above-ground biomass were determined by harvesting the area of one strip at maturity. The plant nitrogen uptake was calculated in both seasons by multiplying $\mathrm{N}$ concentrations in grain or stover by their respective dry weight. 
Table1. The mean and standard deviation values of the main chemical and physical properties of the used soil

\begin{tabular}{lcc}
\hline Parameter & Unit & Value \\
\hline $\mathrm{pH}$ & & ${ }^{8.08 \pm 0.09}$ \\
\hline $\mathrm{ECe}$ & $\mathrm{dSm}$ & $2.11 \pm 0.34$ \\
\hline $\mathrm{CEC}$ & $\mathrm{Cmol} \cdot \mathrm{kg}^{-1}$ & $27.26 \pm 1.45$ \\
\hline Total $\mathrm{CaCO}_{3}$ & $\mathrm{~g} \cdot \mathrm{kg}^{-1}$ & $52.30 \pm 3.33$ \\
\hline $\mathrm{OM}$ & $\mathrm{g} \cdot \mathrm{kg}^{-1}$ & ${ }^{2} 20.60 \pm 0.78$ \\
\hline Available-N & $\mathrm{g} \cdot \mathrm{kg}^{-1}$ & $142.24 \pm 0.89$ \\
\hline Available-P & $\mathrm{g} \cdot \mathrm{kg}^{-1}$ & $105.55 \pm 0.43$ \\
\hline Available-K & $\mathrm{g} \cdot \mathrm{kg}^{-1}$ & $1328.85 \pm 6.43$ \\
\hline Clay & $\mathrm{g} \cdot \mathrm{kg}^{-1}$ & $341.20 \pm 9.22$ \\
\hline Silt & $\mathrm{g} \cdot \mathrm{kg}^{-1}$ & $104.90 \pm 4.23$ \\
\hline Sand & $\mathrm{g} \cdot \mathrm{kg}^{-1}$ & $553.90 \pm 5.87$ \\
\hline Soil texture class & & ${ }^{\dagger}$ S.C.L
\end{tabular}

" Means of three samples \pm SD.

†OM: organic matter; ${ }^{\dagger \dagger}$ S.C.L: sandy clay loam,

\begin{tabular}{|ll|}
\hline $\mathrm{A}$ & $\mathrm{A}$ \\
$\mathrm{A}$ & $\mathrm{A}$ \\
$\mathrm{A}$ & $\mathrm{A}$ \\
\hline
\end{tabular}

soybean

\begin{tabular}{|ll|}
\hline B & B \\
B & B \\
B & B \\
\hline
\end{tabular}

maize

\begin{tabular}{|ll|}
\hline $\mathrm{A}$ & $\mathrm{A}$ \\
$\mathrm{B}$ & $\mathrm{B}$ \\
$\mathrm{A}$ & $\mathrm{A}$ \\
\hline
\end{tabular}

maize + soybean

Fig.1. Diagram showing the arrangement of the rows of soybean (A), maize (B), and soybean/maize intercropping in the plot experiment

\section{Calculations}

Overyielding for grain was calculated as follows:

Overyielding, $\%=\left(Y_{\text {intercrop }}-Y_{\text {sole crop }}\right) / Y_{\text {sole crop }} \mathbf{X} 100$

The land equivalent ratio (LER) is defined as the total land area of sole crops required to achieve the same yields as the intercrops and has been generally accepted as an agronomical sound index to evaluate yield advantage derived from intercropping practice compared with monoculture and is expressed as follows:

Partial Land Equivalent Ratio (PLER) =

$$
\mathbf{Y}_{\text {intercrop }} / \mathbf{Y}_{\text {sole crop }}
$$

Total Land Equivalent Ratio (TLER) $=$

$\left(\mathbf{Y}_{\text {intercropped A }} / \mathbf{Y}_{\text {sole crop A }}\right)+\left(\mathbf{Y}_{\text {intercropped B }} / \mathbf{Y}_{\text {sole crop B }}\right)$

Where $\mathrm{Y}$ intercropped $\mathrm{A}$ and $\mathrm{Y}$ intercropped $\mathrm{B}$ are yields of intercropped crops $\mathrm{A}$ and $\mathrm{B}$, based on land area of whole intercrop system; and $\mathrm{Y}$ sole crop $\mathrm{A}$ and Y sole crop B are yields of monoculture crops A and B. If TLER is greater than 1.00, there is an intercropping yield advantage, and if less than 1.00 , there is no yield advantage (Vandermeer 1989).

TLER indicates the performance of intercropping over sole cropping, whereas PLER and overyielding indicate the performance of an individual intercropped crop relative to the corresponding sole crop.
Statistical Analyses

The one-way analysis of variance (ANOVA) was carried out to determine the statistical significance of the treatment effects on crop yield. Extractable $\mathrm{N}$ and $\mathrm{N}$ uptake were statistically analyzed with the Fisher's least significant difference procedure at a significant level of 0.05 (SAS Institute, 1994). Regression analysis was employed to determine the relationship between metal uptake and grain yield of maize or soybean plants.

\section{RESULTS AND DISCUSSION}

\section{Grain yield and above-ground biomass}

Nitrogen fertilizer application significantly increased the grain yields and above-ground biomass of maize at all rates of $\mathrm{N}$ application (Table 2). However, the above-ground biomass of maize and its dry matter production were lower in monoculture than in intercropping with soybean. No significant differences were recorded between the first and second seasons. Also, the yield of soybean significantly increased with increasing $\mathrm{N}$ application rates up to $25 \%$, but decreased at 50\% RR-N application rate (Table 2). The difference in above ground biomass between cropping systems at the co-growth stage was significant at $\mathrm{N}$ levels of 0,25 , 50 and $100 \%$ RR-N (Table 2). 

The highest grain yield of maize $\left(5580.91 \mathrm{~kg} \cdot \mathrm{ha}^{-1}\right)$ was achieved in maize+soybean intercropping with entire recommended rate of mineral nitrogen application, and the lowest $\left(2280 \mathrm{~kg} \cdot \mathrm{ha}^{-1}\right)$ was achieved in maize+soybean intercropping in absence of mineral nitrogen application (Table 2). On the other hand, application of rhizobium to sole soybean or maize+soybean intercropping system significantly increased maize grain and above-ground biomass yields (Table 2), which were rather promoted at all $\mathrm{N}$ application rates. Although, the intercropping system between maize and soybean plus rhizobium at $50 \%$ of recommended rate of $\mathrm{N}$ fertilizer was not the highest grain yield, it is recommended that to be the most preferable economic treatment. These results were in accordance with the findings of Andersen et al. (2004), Knudsen et al. (2004), and Li et al., (2011). According to Abdel-Motaleb and Yousef (1998), intercropping maize at $25 \%$ or $50 \%$ of its full population density with peanut increased number of pods/plant, 100-seed weight and pod yield/fed.

In general, the effects of $\mathrm{N}$ applied (main treatment) and intercropping (sub-treatment) on grain yields were significant as indicated by LSD test at the $5 \%$ level over two years. On average data, maize grain in maize+soybean intercropping, overyielded that sole maize by $58 \%$ (ranging from $0.9 \%$ to $99.96 \%$ ) (Table 2).

\section{Yield advantage and land-use efficiency}

Total land equivalent ratio (TLER), averaged over $\mathrm{N}$ levels, was 2.30 in maize+soybean, and 2.67 in maize+soybean intercropping with rhizobium over the 2 years of the study (Table 3). This indicates that more area would be required with sole cropping systems to attain the same potential yields of the intercropping systems. TLER was more than 1.0 in both maize+soybean without and with rhizobium intercropping system at all $\mathrm{N}$ application rates in both years (Table 3). Partial land equivalent ratio (PLER) based on grain yield was 1.58 and 0.88 for maize intercropped with soybean, and soybean intercropped with maize, respectively (averaged over two years of study). These values were significantly increased when rhizobium was added in maize+soybean intercropping systems for the two years of study (Table 3 ). The PLER values in terms of biomass and grain yield for intercropped maize + soybean was found to be decreased with increasing nitrogen application rate (Table 3).

The present study supports the hypothesis that yield advantages in cereal/legumes intercropping can be obtained by low rates of $\mathrm{N}$ fertilization. The majority of cereal/legumes intercropping systems are widespread in
Africa (Ndakidemi 2006) and India (Ghosh et al. 2007), and thoroughly studied in details. Songa et al. (2007) found that maize/bean systems had LER values $>1.65$ while some other intercropping with several cereal species including sorghum, and millet, gave LER values $<1$.

\section{Nitrogen acquisition of maize intercropped with soybean}

The total $\mathrm{N}$ content in tissues of maize, soybean and their intercropping system with and without rhizobium for the first and second seasons are shown in Table (4). Nitrogen concentrations in tissues of maize were significantly increased with increasing of $\mathrm{N}$ application rates $(30-120 \mathrm{~kg} \mathrm{~N})$ compared with the control treatment $(0 \mathrm{~kg} \mathrm{~N})$. However, $\mathrm{N}$ content in tissues of soybean was maximized at the lowest $\mathrm{N}$ application rate $(30 \mathrm{~kg} \mathrm{~N})$. These reaction patterns were very similar in both successive seasons (Table 4). The N concentrations of maize in maize+soybean intercropping plots and rhizobium plots were significantly increased in plant tissues and the values were close to the values of $\mathrm{N}$ fertilized plots (Table 4). The combination of mineral and bio-fertilizers in maize+soybean intercropping system showed the highest values of $\mathrm{N}$ concentrations in plant tissues (Table 4) compared with the individual application of mineral-N or bio-fertilizer treatments. The results indicated also that the highest values of $\mathrm{N}$ acquisition was obtained with mineral-N in combination with rhizobium in maize/soybean intercropping followed by maize/soybean and sole maize with mineral-N alone (Table 4). These results were confirmed in the second season. These results are in agreement with the findings of Phillips et al. (2002), Colla et al. (2002), and Nashed et al.,(2004). The highest $\mathrm{N}$ uptake (188.24 kg.ha ${ }^{-1}$ ) was measured in the first season (Table 4) when $\mathrm{N}$ concentrations in grains and stover were recorded at the combination of mineral fertilizer $(120 \mathrm{~kg} \mathrm{~N})$ and maize+soybean+rhizobium intercropping plots (Table 4). In general, nitrogen concentration in maize changed significantly with intercropping under the lower $\mathrm{N}$ fertilizer treatments $(0,25,50$, and $100 \%$ from recommended rate of $\mathrm{N}$ ) in which there were significant differences in $\mathrm{N}$ concentration between the maize intercropped with soybean. Application of $\mathrm{N}$ fertilizer significantly increased $\mathrm{N}$ acquisition by maize. Nitrogen acquisition by maize intercropped with soybean was significantly lower compared to sole maize at all rates of $\mathrm{N}$ application (Table 4). This furthermore reveals that soybean benefitted maize during the co-growth stage. 
Table 3. PLER and TLER in intercropping system of maize and soybean for two successive seasons

\begin{tabular}{|c|c|c|c|c|c|c|}
\hline $\begin{array}{l}\text { Rate of } \mathrm{N} \text { applied } \\
\text { (percentage from } \\
\text { recommended rate) }\end{array}$ & $\begin{array}{l}\text { PLER- } \\
\text { Maize }\end{array}$ & $\begin{array}{l}\text { PLER- } \\
\text { Soybean }\end{array}$ & TLER & $\begin{array}{c}\text { PLER- } \\
\text { Maize } \\
+ \text { rhizobium }\end{array}$ & $\begin{array}{c}\text { PLER- } \\
\text { Soybean } \\
+ \text { rhizobium }\end{array}$ & $\begin{array}{c}\text { TLER } \\
+ \\
\text { rhizobium }\end{array}$ \\
\hline & \multicolumn{6}{|c|}{ Grain Yield, Mgha $^{-1}$} \\
\hline $\begin{array}{r}\text { First Season: } \\
0\end{array}$ & 1.53 & 0.93 & 2.46 & 2.41 & 0.95 & 3.36 \\
\hline $25 \%$ & 2.00 & 0.88 & 2.88 & 2.19 & 0.99 & 3.18 \\
\hline $50 \%$ & 1.79 & 0.85 & 2.64 & 2.04 & 0.96 & 3.00 \\
\hline \multirow{2}{*}{$100 \%$} & 1.01 & 0.87 & 1.88 & 1.01 & 0.94 & 1.95 \\
\hline & \multicolumn{6}{|c|}{ Above-ground biomass, Mgha $^{-1}$} \\
\hline $\begin{array}{r}\text { First Season: } \\
0\end{array}$ & 1.14 & 0.80 & 1.94 & 1.56 & 0.89 & 2.45 \\
\hline $25 \%$ & 1.72 & 0.78 & 2.50 & 1.87 & 0.93 & 2.80 \\
\hline $50 \%$ & 1.65 & 0.76 & 2.41 & 1.79 & 0.92 & 2.71 \\
\hline \multirow[t]{2}{*}{$100 \%$} & 1.01 & 0.80 & 1.81 & 1.01 & 0.94 & 1.95 \\
\hline & \multicolumn{6}{|c|}{ Grain Yield, Mgha $^{-1}$} \\
\hline $\begin{array}{r}\text { Second Season: } \\
0\end{array}$ & 1.53 & 0.92 & 2.45 & 2.42 & 0.93 & 3.35 \\
\hline $25 \%$ & 1.99 & 0.88 & 2.87 & 2.18 & 0.97 & 3.15 \\
\hline $50 \%$ & 1.75 & 0.85 & 2.60 & 2.01 & 0.97 & 2.98 \\
\hline \multirow[t]{2}{*}{$100 \%$} & 1.02 & 0.87 & 1.89 & 1.04 & 0.94 & 1.98 \\
\hline & \multicolumn{6}{|c|}{ Above-ground biomass, Mgha $^{-1}$} \\
\hline $\begin{array}{r}\text { Second Season: } \\
0\end{array}$ & 1.13 & 0.80 & 1.93 & 1.54 & 0.88 & 2.39 \\
\hline $25 \%$ & 1.59 & 0.77 & 2.36 & 1.87 & 0.92 & 2.79 \\
\hline $50 \%$ & 1.63 & 0.76 & 2.39 & 1.78 & 0.91 & 2.69 \\
\hline $100 \%$ & 1.00 & 0.80 & 1.80 & 1.01 & 0.94 & 1.95 \\
\hline
\end{tabular}

Table 4. Nitrogen acquisition $\left(\mathrm{kgha}^{-1}\right)$ of maize, soybean, and maize/soybean intercropping system with and without rhizobium for two successive seasons

\begin{tabular}{|c|c|c|c|c|c|c|c|}
\hline \multirow{2}{*}{$\begin{array}{c}\text { Rate of } \mathbf{N} \\
\text { applied } \\
\text { (percentage from } \\
\text { recommended } \\
\text { rate) }\end{array}$} & \multirow[b]{2}{*}{ Maize } & \multirow[b]{2}{*}{ Soybean } & \multicolumn{2}{|c|}{ Maize + Soybean } & \multirow[b]{2}{*}{$\begin{array}{c}\text { Soybean } \\
+ \\
\text { rhizobium }\end{array}$} & \multicolumn{2}{|c|}{$\begin{array}{c}\text { Maize + soybean } \\
\text { + rhizobium }\end{array}$} \\
\hline & & & Maize & Soybean & & Maize & Soybean \\
\hline$\frac{\text { First Season : }}{0}$ & $3.88 \pm 0.28$ & $5.11 \pm 0.54$ & $4.51 \pm 0.44$ & $4.02 \pm 0.22$ & $9.33 \pm 1.22$ & $6.11 \pm 0.38$ & $4.88 \pm 0.33$ \\
\hline $25 \%$ & $22.33 \pm 2.12$ & $48.45 \pm 3.87$ & $33.78 \pm 3.41$ & $31.09 \pm 1.44$ & $62.25 \pm 5.32$ & $40.12 \pm 4.22$ & $38.65 \pm 2.33$ \\
\hline $50 \%$ & $55.24 \pm 4.87$ & $31.55 \pm 2.66$ & $59.32 \pm 5.66$ & $22.06 \pm 1.65$ & $42.12 \pm 4.88$ & $70.54 \pm 6.74$ & $28.98 \pm 1.66$ \\
\hline $100 \%$ & $165.12 \pm 11.21$ & $44.23 \pm 4.21$ & $177.98 \pm 13.99$ & $31.22 \pm 2.08$ & $48.12 \pm 4.12$ & $188.24 \pm 14.88$ & $39.65 \pm 3.23$ \\
\hline $\mathrm{LSD}_{0.05}$ & 12.28 & 6.23 & 11.18 & 5.12 & 8.88 & 14.25 & 5.32 \\
\hline$\frac{\text { Second Season: }}{0}$ & $6.54 \pm 0.55$ & $5.33 \pm 0.62$ & $4.62 \pm 0.33$ & $3.66 \pm 0.24$ & $9.66 \pm 1.28$ & $6.33 \pm 0.42$ & $4.22 \pm 0.22$ \\
\hline $25 \%$ & $26.25 \pm 3.55$ & $50.12 \pm 3.98$ & $34.00 \pm 3.88$ & $38.12 \pm 2.05$ & $63.23 \pm 5.74$ & $42.00 \pm 4.55$ & $41.45 \pm 3.99$ \\
\hline $50 \%$ & $61.22 \pm 5.01$ & $33.24 \pm 4.02$ & $60.22 \pm 6.12$ & $21.08 \pm 1.99$ & $43.21 \pm 4.15$ & $71.55 \pm 7.18$ & $30.03 \pm 2.32$ \\
\hline $100 \%$ & $171.87 \pm 13.33$ & $46.32 \pm 3.33$ & $179.12 \pm 14.11$ & $34.77 \pm 2.11$ & $49.11 \pm 4.23$ & $192.33 \pm 14.32$ & $43.87 \pm 3.46$ \\
\hline $\operatorname{LSD}_{0.05}$ & 11.47 & 7.14 & 13.58 & 5.43 & 9.21 & 14.88 & 6.08 \\
\hline
\end{tabular}


Fig.(2) depicts nitrogen uptake versus maize grain yield as determined for treatment in first season. There were significant positive relationships between $\mathrm{N}$ uptake $\left(\mathrm{kg} . \mathrm{ha}^{-1}\right)$ and maize grain yield in the first season (Fig.2) [r=0.99, 0.99, 0.90, 0.90, and 0.86 for sole maize, sole soybean, maize/soybean intercropping, soybean-rhizobium, and maize/soybean-rhizobium, respectively]. Similar results were obtained for maize in the north-central USA (Dobermann and Cassman, 2002).

Available nitrogen in soil:

The amounts of available nitrogen in soil before cultivation and after harvest of maize or soybean plants in the two seasons are presented in Table (5). In all treatments, significant increases in available $\mathrm{N}$ content were observed in the mineral and/or bio-fertilized treated plots with maize/soybean intercropping plots (Table 5). However, the mineral-N fertilizers significantly increased available nitrogen in soil followed by the treatment of the maize/soybean intercropping system + biofertilizer plots. The highest value of available nitrogen was $58.32 \mathrm{mgkg}^{-1}$ are widespread recorded at entire RR-nitrogen application compared with the other treatments (Table 5). The amount of available $\mathrm{N}$ in mineral-N plots ranged between 9.66 and $58.32 \mathrm{mg} \mathrm{kg}{ }^{-1}$, while for maize/soybean intercropping treatments, the available nitrogen content values ranged between 7.11 and 22.89

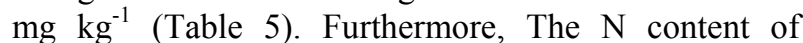
biofertilizer-maize/soybean intercropping treatments ranged between 12.35 and $52.68 \mathrm{mg} \mathrm{kg}^{-1}$ (Table 5). In general, the available nitrogen concentrations were significantly increased to the same extent in mineral-N and bio-fertilized plots (Table 5). These results are in agreement with the findings of $\mathrm{Li}$ et al.2001, Scheller and Raupp, 2005; Warman, 2005, Herencia et al., 2007, and $\mathrm{Li}$ et al.2011).

It is necessary to indicate that the $\mathrm{N}$ applied through the rhizobium or maize+soybean intercropping system was immediately available for plant use. The plots inoculated with rhizobium in presence of mineral-N fertilizer in maize/soybean intercropping system are characterized by higher levels of microbial activity especially at low fertilizers rates of mineral nitrogen (25-50\%) as reported by Melero et al., (2006).

\section{CONCLUSIONS}

The intercropping system between maize and soybean could also be a mean of correcting the low available nitrogen content of most Egyptian agricultural soils, which would mean an improvement in their fertility. Thus, there are benefits to soils from an intercropping system. Moreover, the results confirmed that this intercropping system would be a good substitute for the conventionally used basal fertilization for maize, because it was successfully applied as a source of fertilizer combined with additional mineral fertilizers $(30-60 \mathrm{~kg} \mathrm{~N})$ to complete the overall needs for crops with high requirements, in the case maize.

It is important, therefore, to use the intercropping system between maize and soybean combined with the mineral-N fertilizers $(25-50 \%$ of $\mathrm{N} \mathrm{RR}$, equivalent to $30-60 \mathrm{~kg} \mathrm{~N}$ ) to complete the needs of crops. Although, addition of $50 \%$ of nitrogen RR to maize+soybean plus rhizobium was not the highest value of grain or stover yields, it is recommended that to be the preferable economic treatment.

Table 5. Available nitrogen $\left(\mathrm{mgkg}^{-1}\right)$ in the soil before cultivation and after harvest of maize, soybean, and maize intercropped with soybean plants for two successive seasons (means \pm SD)

\begin{tabular}{ccccccc}
\hline $\begin{array}{c}\text { Rate of N applied } \\
\text { (percentage from } \\
\text { recommended rate) }\end{array}$ & Before & Maize & Soybean & $\begin{array}{c}\text { Maize }+ \\
\text { Soybean }\end{array}$ & $\begin{array}{c}\text { Soybean } \\
+ \\
\text { rhizobium }\end{array}$ & $\begin{array}{c}\text { Maize }+ \\
\text { Soybean } \\
+ \text { rhizobium }\end{array}$ \\
\hline $\begin{array}{c}\text { First Season: } \\
0\end{array}$ & $9.66 \pm 0.61$ & $6.23 \pm 0.37$ & $9.72 \pm 0.55$ & $7.11 \pm 0.88$ & $15.33 \pm 1.03$ & $12.35 \pm 0.77$ \\
\hline $25 \%$ & $16.22 \pm 0.87$ & $7.89 \pm 0.56$ & $28.98 \pm 2.22$ & $15.23 \pm 1.04$ & $48.99 \pm 4.55$ & $44.24 \pm 3.45$ \\
\hline $50 \%$ & $28.05 \pm 1.11$ & $9.23 \pm 0.32$ & $31.22 \pm 2.36$ & $19.25 \pm 2.88$ & $51.88 \pm 4.87$ & $47.88 \pm 5.14$ \\
\hline $100 \%$ & $58.32 \pm 1.77$ & $11.25 \pm 1.02$ & $35.65 \pm 3.58$ & $22.89 \pm 3.77$ & $55.33 \pm 5.23$ & $52.68 \pm 4.56$ \\
\hline LSD 0.05 & $\mathbf{3 . 9 9}$ & $\mathbf{1 . 9 2}$ & $\mathbf{2 . 0 8}$ & $\mathbf{1 . 3 2}$ & $\mathbf{4 . 9 5}$ & $\mathbf{4 . 8 8}$ \\
\hline $\begin{array}{c}\text { Second Season: } \\
0\end{array}$ & $10.88 \pm 1.08$ & $7.88 \pm 0.88$ & $11.98 \pm 0.77$ & $9.12 \pm 1.08$ & $16.88 \pm 1.11$ & $14.58 \pm 1.55$ \\
\hline $25 \%$ & $18.22 \pm 1.55$ & $9.11 \pm 2.01$ & $32.65 \pm 3.58$ & $17.25 \pm 2.11$ & $49.98 \pm 4.55$ & $46.54 \pm 4.35$ \\
\hline $50 \%$ & $31.22 \pm 2.33$ & $10.56 \pm 1.04$ & $34.78 \pm 4.32$ & $22.54 \pm 3.87$ & $53.68 \pm 5.66$ & $47.99 \pm 3.45$ \\
\hline $100 \%$ & $62.32 \pm 5.66$ & $13.21 \pm 1.12$ & $37.25 \pm 3.69$ & $25.34 \pm 3.54$ & $58.35 \pm 3.45$ & $54.98 \pm 4.21$ \\
\hline LSD 0.05 & $\mathbf{3 . 8 7}$ & $\mathbf{1 . 8 4}$ & $\mathbf{2 . 8 4}$ & $\mathbf{1 . 5 6}$ & $\mathbf{5 . 1 1}$ & $\mathbf{5 . 3 6}$ \\
\hline
\end{tabular}



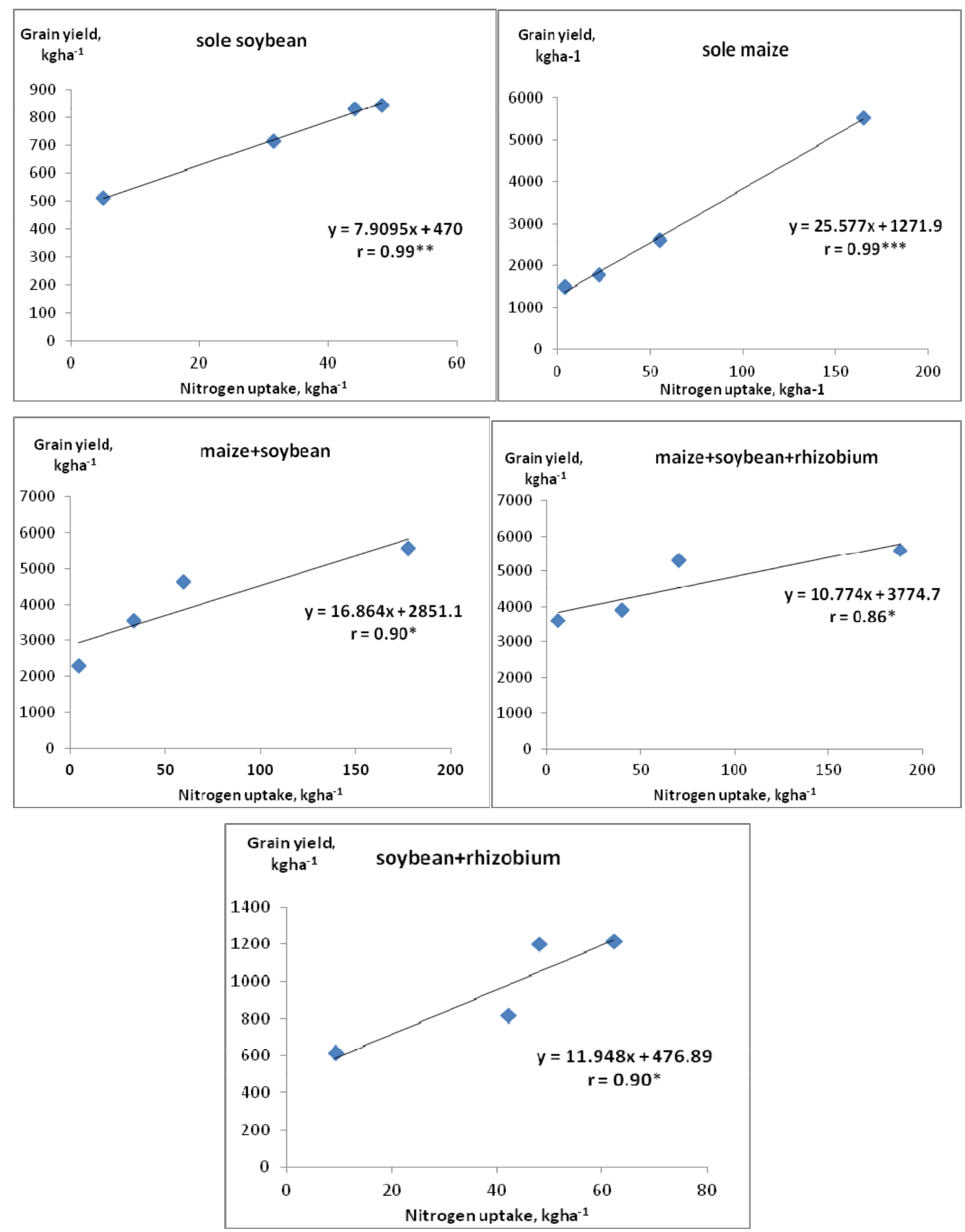

Fig2. Relationships between nitrogen uptake and grian yield of sole maize or soybean, and maize/soybean intercropping system with and without rhizobium inoculation.

$*, * *, * * *$ are significant at $0.05,0.01,0.001$ probability levels, respectively 


\section{REFERENCES}

Abd-Emotaleb,H.M. and Yousef, M.S.H. (1998). Intercropping maize with two varieties of peanut under of two levels of nitrogenous fertilizer. Proc. $8^{\text {th }}$ Conf.Agron., Suez Canal Univ. Ismailia,Egypt,28-29 Nov.(544-552).

Allen JR, and Obura K (1983) Yield of corn, cowpea, and soybean under different ntercropping systems. Agron J 75:1005-1009.

Andersen MK, Hauggaard-Nielsen H, Ambus P, and Jensen ES (2004) Biomass production, symbiotic nitrogen fixation and inorganic $\mathrm{N}$ use in dual and tri-component annual intercrops. Plant Soil 266:273-287.

Bremner,J.M. and Mulvaney,C.S.(1982). Nitrogen-Total Pp.595-623.In A.L. Page, R.H.Miller, and D.R. Keeney(eds). Methods of Soil Analysis, American Society of Agronomy, Madison, Wisconsin, USA.

Cahill JF (2002) What evidence is necessary in studies which separate root and shoot competition along productivity gradients? J Ecol 90:201-205.

Colla, G., Mitchell J.P., Poudel D.D., and Temple.S.R. (2002). Changes of tomato yield and fruit elemental composition in conventional,low input, and organic systems. J. Sustain. Agric. 20:53-67.

Day, P.R.(1965). Particle Fraction and Particle Size Analysis Pp: 545-566.In A.C. Black, D.D. Evans, L.E. Ensminger, J.L. White, and F.E. Clark (eds.). Methods of soil analysis. Part I. american society of agronomy, Madison, Wisconsin, USA.

Dobermann, A., and Cassman, K.G. (2002). Plant nutrient management for enhanced productivity in intensive grain production systems of the United States and Asia. Plant Soil 247: 153-175.

Francis,CA.(1989).Biological effeiciencies in mixed multiplecropping ystems.Adv.Agron.42:1-42.

Ghosh PK (2004) Growth, yield, competition and economics of groundnut/cereal fodder intercropping systems in the semiarid tropics of India. Field Crop Res 88:227-237.

Ghosh PK, Bandyopadhyay KK, Wanjari RH, Manna MC,Misra AK, Mohanty M, and Rao AS (2007) Legume effect for enhancing productivity and nutrient useefficiency in major cropping systems - an Indian perspective: a review.J Sustain Agric 30:59-86

Hauggaard-Nielsen H, and Jensen ES (2001) Evaluating pea and barley cultivars for complementarity in intercropping at different levels of soil $\mathrm{N}$ availability. Field Crops Res 72:185-196.

Herencia, J. F. ; Ruiz-Porras J. C.; Melero S.; Garcia-Galavis P. A.; Morillo E.; and Maqueda C.(2007). Comparison between organic and mineral fertilization for soil fertility levels, crop macronutrient concentrations, and yield.Agron.J.99:973-983.
Horst WJ, and Waschkies C (1987) Phosphorus nutrition of spring wheat (Triticum aestivum L.) in mixed culture with white lupin (Lupinus albus L.). Z Pflanzernähr Bodenkd 150:1-8.

Jensen ES (1996) Grain yield, symbiotic N-2 fixation and interspecific competition for inorganic $\mathrm{N}$ in pea-barley intercrops. Plant Soil 182:25-38.

Jones, J.B. (2001). Laboratory guide of conducting soil tests and plant analysis. CRC Press. New York, Washington, D.C. Kavamahanga F, Bishnoi UR, Aman K (1995) Influence of different $\mathrm{N}$ rates and intercropping methods on grain sorghum, common bean, and soya bean yields. Trop Agric 72:257-260.

Knudsen,D., Peterson,G.A., and Pratt,P.F.(1982). Lithium,sodium and potassium.p225-245. In A.L. Page, R.H.Miller, and D.R. Keeney(eds). Methods of Soil Analysis, American Society of Agronomy, Madison, Wisconsin, USA.

Knudsen MT, Hauggaard-Nielsen H, Jornsgard B, and Jensen ES (2004) Comparison of interspecific competition and $\mathrm{N}$ use in pea-barley, faba bean-barley and lupin-barley intercrops grown at two temperate locations. J Agric Sci 142:617-627.

Li ,Q.Z., Sun ,J.H., Wei,P.Christie X.J., Zhang F.S., and Li,L.(2011). Overyielding and interspecific interactions mediated by nitrogen fertilization in strip intercropping of maize with faba bean, wheat and barley. Plant Soil (2011) 339:147-161.

Li L, Sun JH, Zhang FS, Li XL, Yang SC, and Rengel Z (2001) Wheat/maize or wheat/soybean strip intercropping I. Yield advantage and interspecific interactions on nutrients. Field Crop Res 71:123-137.

Li L, Li SM, Sun JH, Zhou LL, Bao XG, Zhang HG, and Zhang FS (2007) Diversity enhances agricultural productivity via rhizosphere phosphorus facilitation on phosphorusdeficient soils. Proc Natl Acad Sci USA 104:11192-11196.

Liu GC (2005) Difference and its mechanism of interspecific nutrition competition in different intercropping systems. Dissertation, Gansu Agricultural University, China.

Loreau M, Naeem S, Inchausti P, Bengtsson J, Grime JP, Hector A, Hooper DU, Huston MA, Raffaelli D, Schmid B, Tilman D, and Wardle DA (2001) Biodiversity and ecosystem functioning: current knowledge and future challenges. Science 294:804-808.

Melero, S., Ruiz,J.C.,Herencia, J.F., and Madejon E. (2006). Chemical and biochemical properties in a silty loam soil under conventional and organic management. Soil Tillage Res. 90:162-170.

Nashed,N.Sh , Daoud A.M.,and Soliman, M.S.(2004).Yied potentials and nutrient composition in maize and peanut in relation to intercropping system at variable $\mathrm{Ca} / \mathrm{Na}$ levels of saline irrigation water .Minufiya J..Agric. Res. Vol 29(4):1029-1044. 
Ndakidemi PA (2006). Manipulating legume/cereal mixtures to optimize the above and below ground interactions in the traditional African cropping systems. Afr J Biotechnol 5:2526-2533

Nelson, D.W., and Sommers, L.E.(1982). Total carbon, organic carbon and organic matter. pp. 539-549. In A.L. Page, R.H. Miller, and D.R. Keeney (eds.). Methods of soil analysis, American Society of Agronomy, Madison, Wisconsin, UAS.

Nelson, R.E.(1982). Carbonate and gypsum. pp. 181-197. In A.L. Page, R.H. Miller, and D.R. Keeney (eds.). Methods of soil analysis, American Society of Agronomy, Madison, Wisconsin, USA.

Olsen, S.R, and Sommers, L.E. (1982). Phosphorus. pp:403427. In A.L. Page, R.H. Miller, and D.R. Keeney (Eds.). Chemical and microbiological properties. 2nd edition, American Society of Agronomy, Madison, Wisconsin.

Phillips, S.B., Mullins,G.L., and Donohue, S.J.(2002). Changes in snap bean yield, nutrient composition, and soil chemical characteristics when using broiler litter as fertilizer source. J. Plant Nutr. 25:1607-1620.

Rhoades, J.D. (1982). Cation exchange capacity. pp.149-157. In A.L. Page, R.H. Miller, and D.R. Keeney (eds.). Methods of soil analysis, American Society of Agronomy, Madison, Wisconsin, USA.

Richards, L.A. (1954). Diagnosis and improvement of saline and alkaline soils. USDA. Handbook 60. US Government Printing Office, Washington, DC.

SAS Institute. (1994). SAS/STAT User's Guide. Version 6.4th edition. SAS Inst., Cary, N.C.
Scheller, E., and Raupp,J.(2005). Amino acid and soil organic matter content of topsoil in a long term trial with farmyard manure and mineral fertilizer. Biol. Agric. Hortic. 22:379397.

Sharaiha R, and Gliessman S (1992) The effects of crop combination and row arrangement in the intercropping of lettuce, favabean and pea on weed biomass and diversity and on crop yields. Biol Agric Hortic 9:1-13

Snaydon RW (1982) Root and shoot interactions between barley and field beans when intercropped. J Appl Ecol 19:263-272.

Songa JM, Jiang N, Schulthess F, and Omwega C (2007) The role of intercropping different cereal species in controlling lepidopteran stemborers on maize in Kenya. J Appl Entomol 131:40-49

Vandermeer JH (1989) The ecology of intercropping. Cambridge University Press, Cambridge

Warman, P.R. (2005). Soil fertility, yield and nutrient contents of vegetable crops after 12 years of compost or fertilizer amendments. Biol. Agric. Hortic. 23:85-96.

Zhang LZ, van der Werf W, Zhang S, Li B,and Spiertz JHJ (2007) Growth, yield and quality of wheat and cotton in relay strip intercropping systems. Field Crop Res 103:178-188.

Zhang LZ, Spiertz JHJ, Zhang S, Li B, and Van der Werf W (2008) Nitrogen economy in relay intercropping systems of wheat and cotton. Plant Soil 303:55-68 160 Plant Soil (2011) 339:147-161.

Zuo YM, Zhang FS, Li XL, and Cao YP (2000) Studies on the improvement in iron nutrition of peanut by intercropping with maize on a calcareous soil. Plant Soil 220:13-25 


\section{الملضص العرب}

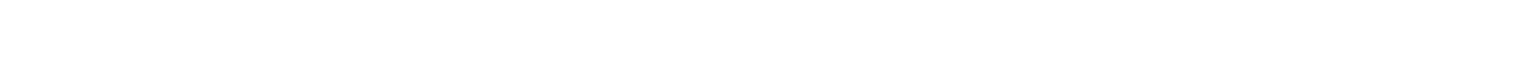 والصلحية الحيوبة للنيتروجن ف وجود النيتروجن المعنف \\ نيفين عمر فتهى}

فى كلاموطوى النمو. زادت الصلاحية الحيوية للنيتروجين

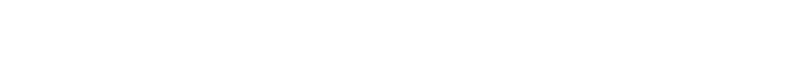

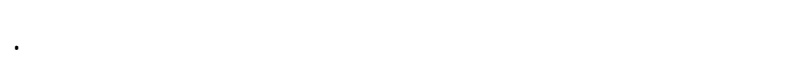

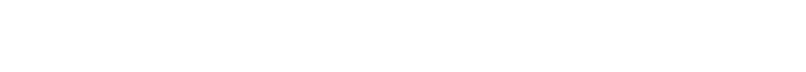

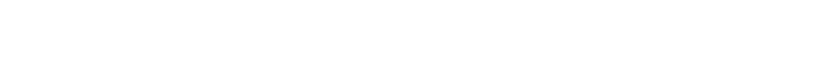

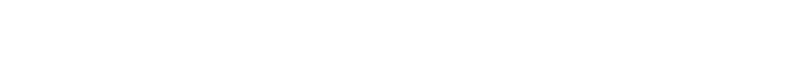

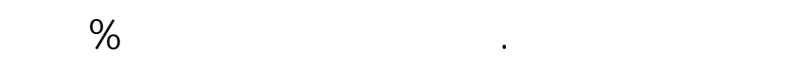

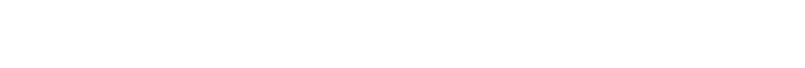

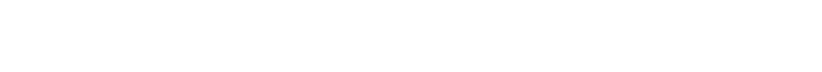

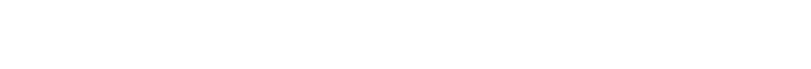

إقتصاياً.

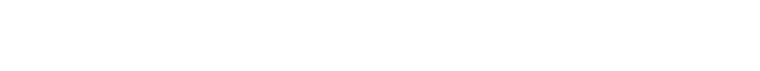

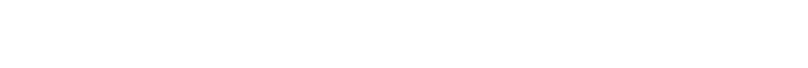

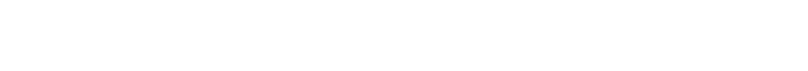

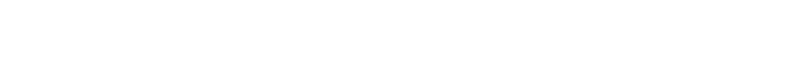

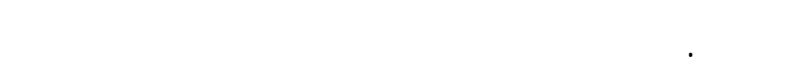

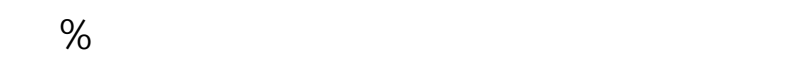

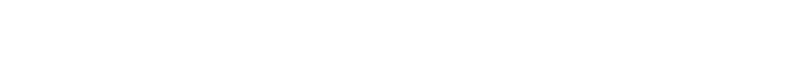
.

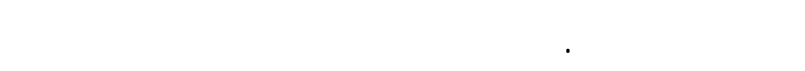

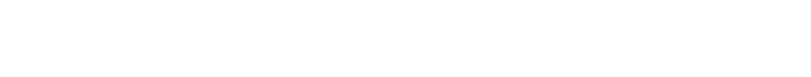

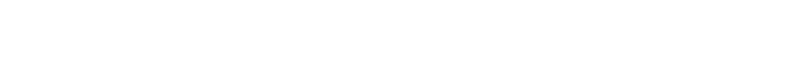

